年次大会・計装技術セッションA

\title{
製紙設備の最新ドライブ技術
}

\section{New Technology of Electrical Drive Equipment for Paper Manufacturing Systems}

株式会社安川電機 濱 田 兼 幸

\author{
Kaneyuki Hamada \\ YASKAWA ELECTRIC CORPORATION
}

The paper presents four issues. The 1st is the introduction of the new web-tension control method which is useful for the control of paper-machine and versatile converting machines. The 2 nd is the performance in efficiency and torque control of GTO inverter which have been successful for energy-saving and center-drive-winder. The 3 rd is the software-package for the maintenance of inverters. The last is the introduction of smart controller which is useful for revamping or improvement of old control-systems.

\section{1. 概 要}

製紙産業に限らず日本の製造業をとりまく環境の变 化は，ここ数年すさまじいものがあり，

- 年間総労働時間短縮に見られる人的資源の逼迫

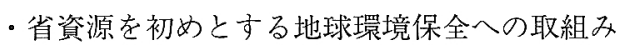

・国際環境の大きな変化

などへの迅速な対応をせまられている。

これらをドライブ技術の観点で考えて見れば，一層 の高性能化による製品（紙，複合製品など）の品質・ コスト・流通面での差別化は, 徒来とかわらない二ー ズであるが,

・省エネルギ

・自動化などによる省力, 省オペレーション

・省保全

・省スペース（改造，更新のやりやすさ）

などが，ますます重要なファクターになりつつある。

幸い,ここ10 年のエレクトロニクス分野の進歩は, インバータに代表されるパワー分野，PCに代表され るマイクロエレクトロニクスともめざましいものがあ り，ようやく，もろもろの課題に対する実用面での本 格的ブレークスルーが出来つつある。

ここでは，

・高性能化ヒウェブ張力制御

・省エネルギーヒ高効率高圧 GTO インバー夕
・省保全ヒインバータ保全ツール

・省スペースヒコントローラのダウンサイジング などについて，最近の技術，取り組みを紹介する。

\section{2. 張力制御系へのアドバンスト制御手法の 応用}

抄紙機，塗布機，ワインダなど多くの代表的製紙・ 加工機械でウェブの張力が素材の安定搬送，ロール製 品の品質に大きく係わっているにも拘らず，インバー タなどの独立したドライブ装置の中で, ファームウェ ア的に実行される速度制御やトルク制御に比べ，張力 制御性向上へのアプローチは，PID 制御に代表され る従来方式が今だ主流であり, ある程度残留振動を許

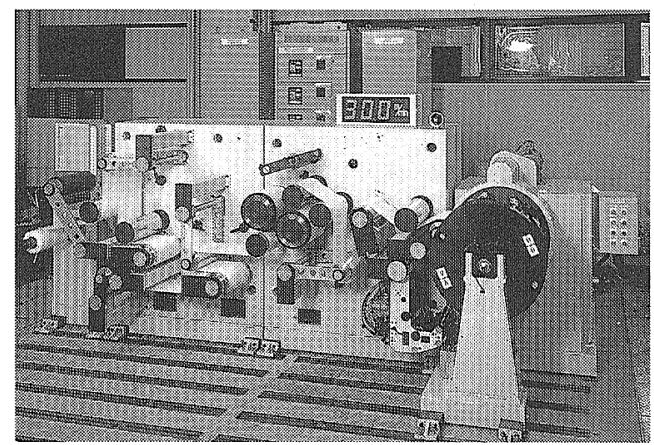

図 1 ラボマシンの全景 
容してきたことも事実である。

安川電機では, 図 1 に示すラボマシンとドライブ装 置を組み合わせて，ドライブ装置，素材までを含めた 機械系のモデリングを行い, 現実に操業上発生する各 種の外乱に対して最も有効な制御方式を確立した。
図 2 は，操業上発生する外乱要因と機械及び一般的 制御系構成を示すものであるが，張力制御系のみなら ず，速度，トルク制御系についても，ウェブ張力制御 の観点から最適な性能を引き出す方式へと総合的に改 良を加えることで各種の効果が達成できた。例えば，

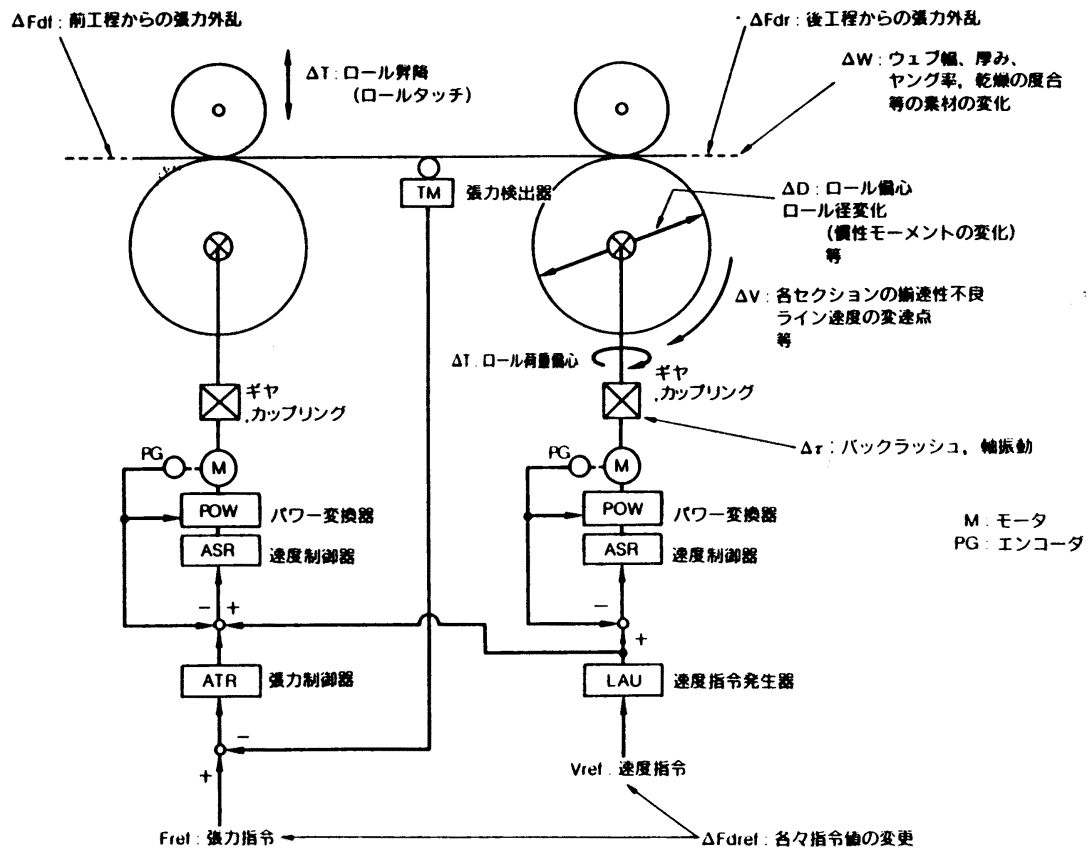

図 2 張力制御系構成図

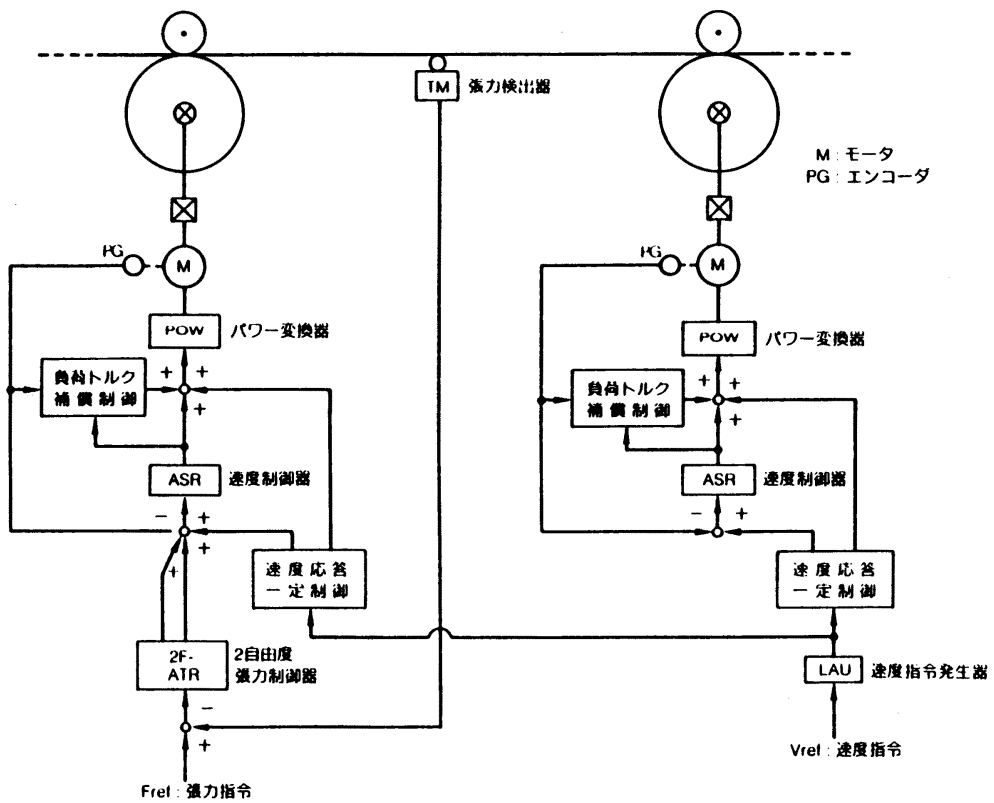

図 3 新張力制御系の構成 


\begin{tabular}{lll} 
濱田兼幸 \\
\hline
\end{tabular}

軸ねじり振動やギャバックラッシュが及ぼす悪影響の 低減などである。

具体的に実施したアドバンスト制御手法は,

・制御構造の 2 自由度化

- 速度応答一定制御付加

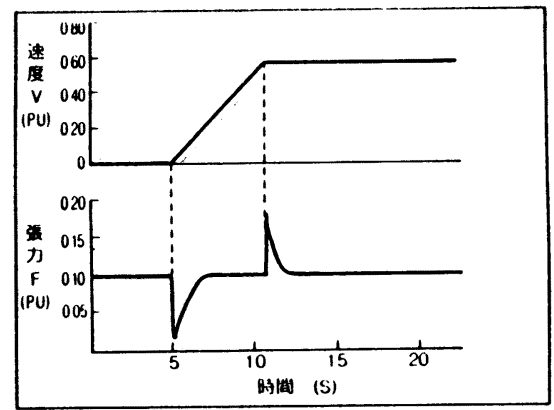

(a) 往来の桠的式

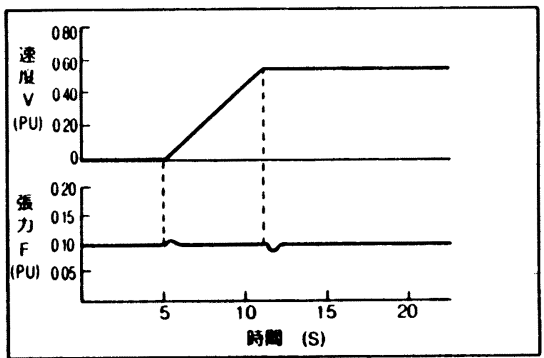

(b) 橉桶方式

図 4 ライン加減速特性

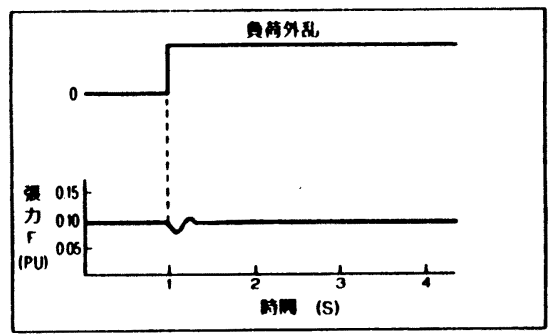

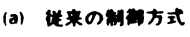

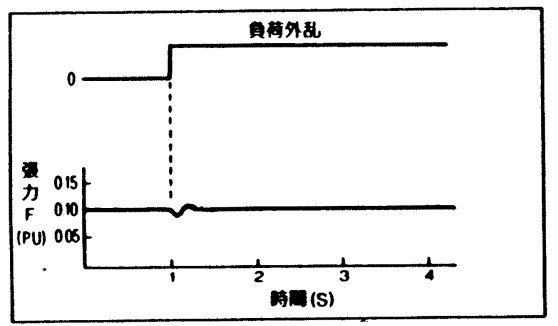

(b) 新新方式

図 5 負荷外乱応答特性
・負荷トルク補償制御 が主なものである。

図 3 に，新張力制御系の構成を示している。

図 4〜図 6 に外乱に対する張力制御の改善結果を示 している。

但し, 実設備への適用にあたっては, 確かに今迄べ テランの調整を必要としていた部分がアドバンストな 大わざの制御にとって変えることができるが，それは 逆に既存の技術では難解な部分をあわせ持っているこ とを意味しており，誰でも調整可能なチューニング技 術や制御系のユーザインタフェースとしての取り組み が残っている。

\section{3. 効率 $99 \%$ 超高圧 GTO インバータ}

日本の製紙業界においては，外国に先駆けて省保全 の観点から, 直流機にかわってセクション駆動の AC 化や省エネ目的のファン・ポンプなどの可変速化が実

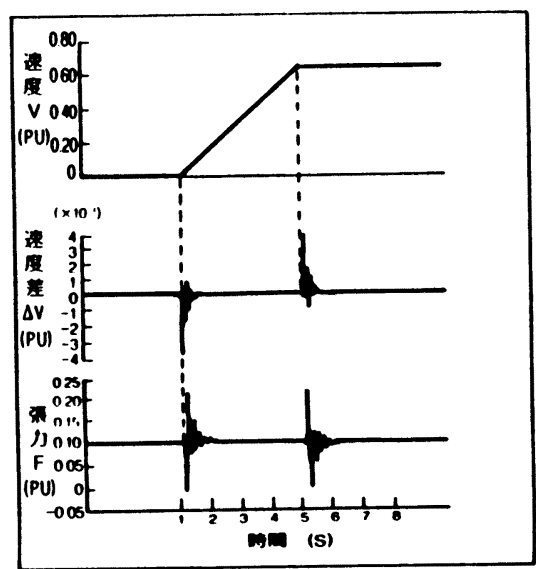

(a) 谟来の新部方式

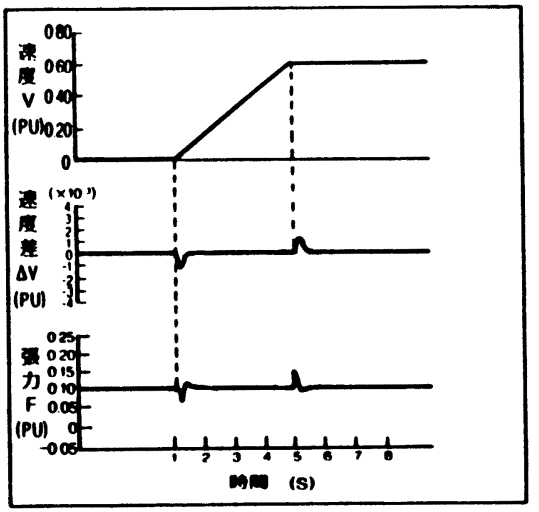

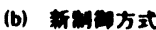

図 6 軸ねじり振動の抑制 
施されてきている。

しかし, 定出力範囲の広いワインダや大容量ファン などでは，イニシャルコスト回収評価や図 7 に示す中 大容量ドライブが抱えていた課題面からインバータの 適用が今一歩進んでいないといえる。

最近, 非常に変換効率の高い $3,300 \mathrm{~V}$ ダイレクト 駆動可能な高圧大容量インバー夕（製品名 VS-683 GT 3) をボイラの大形ドラフトファンや鉄鋼のテン ションリール (センタワインダ) への適用がユーザ各 位のご支援・ご協力のもとに成功を収めたのでここに， その特徴の一部を紹介する。

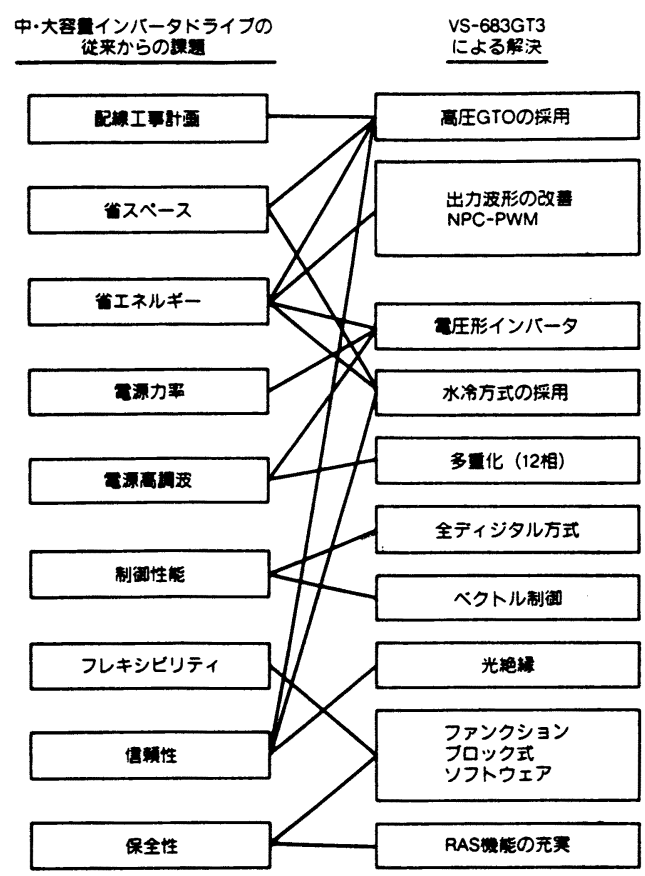

図 7 中大容量インバータドライブの課題と解決

\section{1 配線工事費の低減}

高圧ケーブルが利用できること, 出力変圧器を省略 できることなどにより, 数百万円単位で設備工事関係 の費用を節約できる。

\section{2 高効率による省エネルギー}

大容量ドライブでは, インバー夕変換効率の大小は 採用検討に際して最も重要なファクタである。

仮に $2,000 \mathrm{~kW}$ モータドライブで $5 \%$ の効率差は $100 \mathrm{~kW}$ の損失差である。 $3.3 \mathrm{kV}$ の高圧多イレクト 化と出力波形改善によるモー夕効率向上により, 低圧 駆動化と比較して大幅な効率アップが実現できている。 図 8 にインバー夕単体での効率を, 表 1 には, 1,800 $\mathrm{kW}$ ブロワでの低圧サイリスタシステムとの総合比較 を示している。

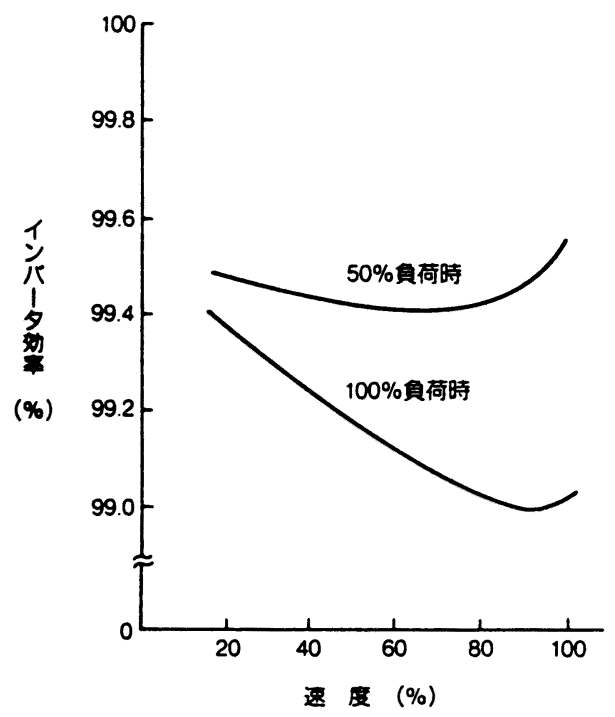

図 8 インバー夕の変換効率

表 1 GTO インバータと電流形サイリスタインバータの比較

\begin{tabular}{|c|c|c|}
\hline 評価項目 & $\begin{array}{l}\text { NPC-PWM 高压 } \\
\text { GTO インバータ }\end{array}$ & $20^{\circ}$ 移相差 3 並列多重電流形インバータ \\
\hline 機器設置スペース & $\begin{array}{c}1\left(14 \mathrm{~m}^{2}\right) \\
\text { 入力トランス含む }\end{array}$ & $\begin{array}{c}2.9\left(41 \mathrm{~m}^{2}\right) \\
\text { 入出力トランス含む }\end{array}$ \\
\hline 冷却方式 & 純水による冷却 & 風 冷 \\
\hline 総合効率（全負荷時） & $94.5 \%$ & $90.4 \%$ \\
\hline 電源力率 & 0.96 & 0.68 \\
\hline 配線工事 & $\begin{array}{l}\text { 主回路は高圧入出力 } \\
\text { ケーブルのみ }\end{array}$ & 高圧入出力ケーブル +3 芯 $/ 20 \mathrm{~m}$ の主回路配線が 24 回線要 \\
\hline
\end{tabular}




濱田兼幸

\section{3 制 御 性能}

IGBT 素子も含めてパワトランジス夕によるインバ 一タドライブ性能については, 直流レオナードを超え た性能を有していることについては，もはや知られて いる。一方，高圧大容量化を可能にした GTO 素子は 従来のサイリス夕素子に比べると自己消弧素子である という利用はあるものの，トランジス夕に比べ，とく にスイッチング速度にまだまだ弱点をもっている。し

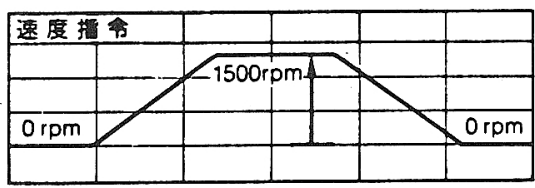

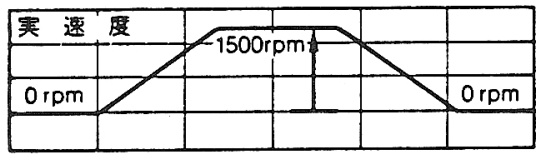
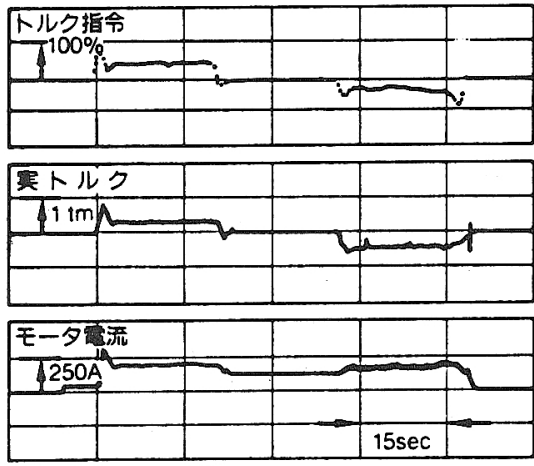

図 9 加減速特性

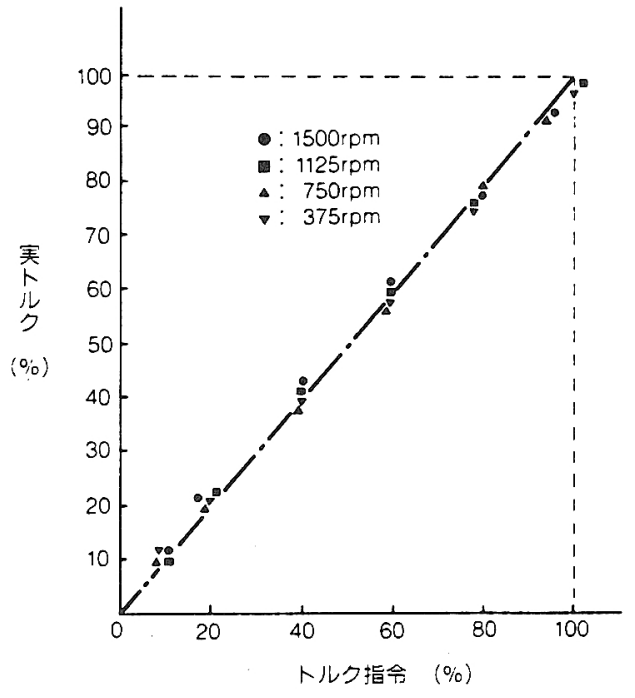

図 10 トルク制御特性
かしながら，新しい波形方式（NPC-PWM）などの 工夫により，センタドライブ巻取にも十分適用可能な 特性を達成している（図 9, 図 10）。

4. インバータ保全ツール

ドライブの $\mathrm{AC}$ 化，ディジタル化，アドバンスト 化により，

・パラメータの数が増え，ドライバ・モータ交換に
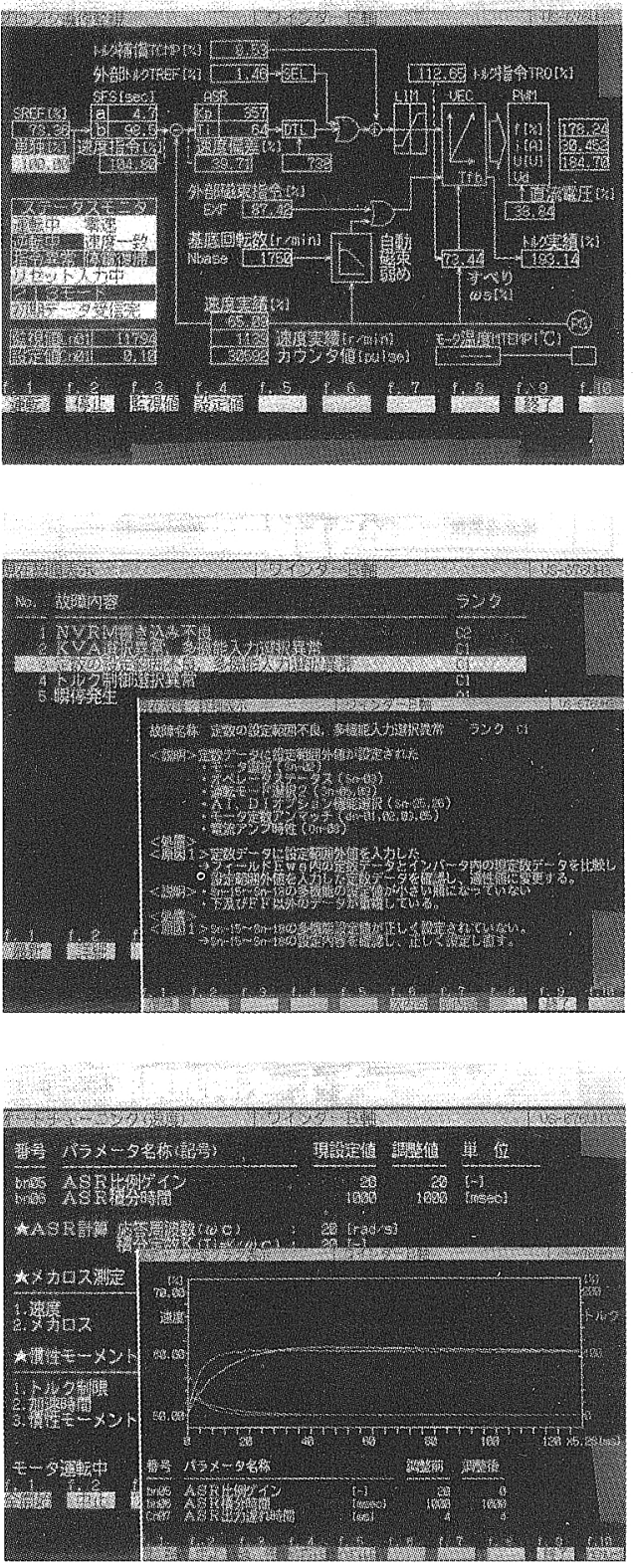

図11 インバータ保全ツールの表示例 
手間がかかる。

・予備モータの数が多く, 管理が大変。

・異常時のトラブルシューティングが難解。

・メーカでのモータ組み合わせテストを実施しない

と良い性能が出せない。

など，例えばブラシメンテフリーと引き替えに保全サ

イドに厄介な課題を残してきたことも事害である。

もちろん，上位のコントローラと組み合わせて MMI やエンジニアリングワークステーション上で, かなりのレベル迄の RAS 機能を達成しているコント ローラ (PLC) 系も存在しているが, 機能面, 取扱 性面で必ずしも十分とはいえなかった。しかし，高性 能 PCの普及とともに, 図 11 の例に示すように,

・一貫性の高い運転監視機能

・ペーパレス故障ガイダンス

・インバータ・モータ定数のチューニング

・テストレポート作成管理

・データレコーダ機能

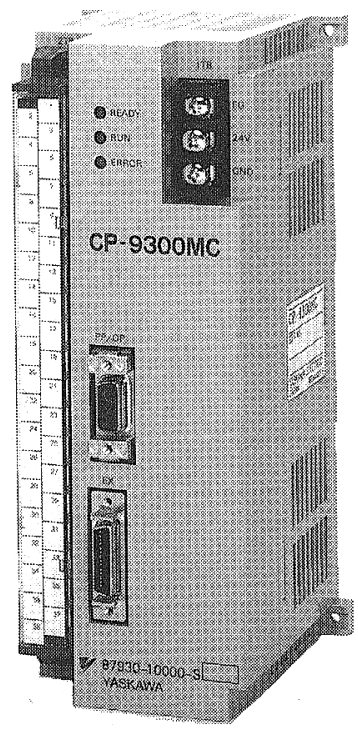

図 12 小形コントローラ

表 2 小形コントローラのソフトウエア仕様

\begin{tabular}{|c|c|}
\hline 項 & 仕 \\
\hline $\begin{array}{l}フ^{\circ} \text { グ ム } \\
\text { 実行制御方式 }\end{array}$ & $\begin{array}{l}\text { 定周期スキャンカ式（高速・低速 } 2 \text { レベル） } \\
\text { 高速スキャンタイム設定：1〜 } 30 \mathrm{~ms}(1 \mathrm{~ms} \text { 単位) } \\
\text { 低速スキャンタイム設定：1 300 ms（1 ms 単位) }\end{array}$ \\
\hline 基 本 命 令 語 & $\begin{array}{lr}\text { シーケンス命令 } & 7 \text { 種 } \\
\text { 数值演算命令 } & 26 \text { 種 } \\
\text { 制御命令 } & 9 \text { 種 } \\
\text { 組み込み関数 } & 4 \text { 種 } \\
\text { データ転送命令 } & 2 \text { 種 } \\
\text { DDC 命令 } & 12 \text { 種 } \\
\text { システム関数 } & 4 \text { 種 } \\
\text { ユーザー関数 } & 10 \text { 種 登録可能 }\end{array}$ \\
\hline 基本データタイプ & $\begin{array}{l}\text { リレー（ビット） } \\
\text { 整数 }(-32,768 \sim+32,767) \\
\text { 倍長整数 }(-2,147,483,648 \sim+2,147,483,647)\end{array}$ \\
\hline 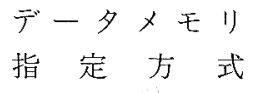 & $\begin{array}{l}\text { レジスタ番号またはリレ一番号（シンボル指定可） } \\
\text { 添字による修飾可（2 種） }\end{array}$ \\
\hline 図面 の 数 & $\begin{array}{ll}\text { 登録図面数 } & \text { 最大 } 30 \text { 画面 } \\
\text { ステップ数 } & 300 \text { ステップ/DWG (関数) } \\
\text { DWGの種別 } & \mathrm{A}: \text { 始動, } \mathrm{H}: \text { 高速, L L : 低速 } \\
\text { DWGの階層 } & 2 \text { 階層 }\end{array}$ \\
\hline 基本命令実行時間 & $\begin{array}{ll}\text { シーケンス命令 } & 1.7 \mu \mathrm{s} \\
\text { 四則演算 (整数) } & 0.44 \sim 1.44 \mu \mathrm{s}\end{array}$ \\
\hline
\end{tabular}


などを汎用パソコン上で実施できるようになった。

ここで紹介した保全ツールでは，1枚のフロッピー で 255 台までのドライブセクションを名前に対応して 管理できるため, 1 つのペーパミル全体のドライブの パラメータや更には，保全記録までサポートできる。

こうした機能により, 予備モー夕数の低減, 異メー カモータの暫定代替, 速度センサ異常時のセンサレス ベクトルでの暫定運転など, MTTRの短縮といった 面でも，色んな可能性が考えられるようになった。

\section{5. コントローラのダウンサイジング}

従来, 径演算に代表される巻取機の制御や複数セク ションにまたがる比率ドロー制御には中大形のシステ ムコントローラ (PLC) を適用してきたが, 旧い設 備の部分更新や小規模設備では, ドライブ装置とのイ ンタフェースや設置スペース, さらには予算面でも不 釣り合いの場合が多かった。ここで紹介する小形コン トローラ CP-9300は,

・システムコントローラの演算, シーケンス機能を 有す。

・小形で簡単に取付, 取扱いできる。

・従来のアナログ制御代替可能なインタフェースを
有す。

・高速パルス入力も含めたアナログ $\mathrm{I} / \mathrm{O}, \mathrm{P}-\mathrm{I} / \mathrm{O}$ が オンボードに搭載している。

などの特長があり, 中形システムコントローラをダウ ンサイジングしたものといえる。

表 2 にソフトウェア基本仕様を示すが, プログラム 容量, メモリ容量が $\mathrm{I} / \mathrm{O}$ 数相当しか用意されてない ことを除けば, 中大形システムコントローラと比べて も遜色ない。旧式 MRH のリプレースやアナログ式 巻取制御, 比率制御の周辺リレーシーケンスも含めた 更新などに使用できる。その為に各種のパッケージや パソコンと組み合わせた試運転調整機能も用意されて いるので, 電機メーカの手を借りなくて, ユーザが自 ら設計・エンジニアリング出来る道が開かれている。

\section{6. 最 後 に}

ユーザが抱えるもろもろの課題に対し，ようやくブ レークスルーが見えてきたが，我々をとりまく環境は， それ以上のピッチで変化している。

真のメンテナンスフリー, 調整フリー化実現のため には，まだ多くの課題が残されており，一層の努力を してゆきたい。 